mission of sensitive impressions : therefore I could not make the error I am accused of. If there is an error in this respect, it consists in having attributed to Sir Charles Bell a view which he never had; and this error has not been made by me.

The anonymous writer in THE LANCET says that the rules of diastaltic actions might explain many facts which $I$ have considered as effects of painful sensations. It seems to me that if this writer had been acquainted with the rules of diastaltic [actions?], so graphically laid down by Dr. Marshall Hall, he would not have spoken as he has.

Hoping, Sir, that you will find room in your next number for this letter,

Paris, April, 1856

$$
\text { I remain, very respectfully, yours, }
$$

$$
\text { Ed. Brown-Skquard, M.D. }
$$

* * We insert the above in the spirit of fairness, though we think that if M. Brown-Séquard had waited to see our subsequent articles, he would have wished it suppressed. We have duly allotted to Sir Charles Bell and to M. Brown-Séquard their just proportion of merit in this inquiry-to the former, originality; to the latter, progress. The experiments of Prof. J. Müller, who concludes, "These experiments place beyond all doubt the truth of Bell's doctrine," shonld not be omitted in this interesting discussion. It should be remembered that $\mathrm{Mr}$. Cæsar Hawkins was a pupil of Sir Charles Bell, and therefore well acquainted with his labours. Is M. Brown-Séquard's reference to M. Paul Broca quite generous? With regard to the distinction between the seat and the transmission of sensation, in reference to Sir C. Bell, we fear M. Brown-Séquard repeats his first misapprehension. The truth is, that neither the style nor the logic of either Sir Charles Bell or M. BrownSéquard is extremely lucid.-ED. I.

\section{THE LATE ELECTION OF MEDICAL OFFICER FOR ST. GEORGE'S, HANOVER SQUARE. To the Editor of THE LANCET.}

SrR,-I have the honour to lay before you the following facts :-

At the end of November last (having the intention of offering myself as a candidate for the appointment of Officer of Health for the parish of St. George, Hanover-square), I wrote to Mr. Simon, the Medical Officer of the Board of Health, for a testimonial of titness, feeling that it would weigh very much with the public. To that application I received the following reply: "General Doard of Health, Whitehall, Nov. 30th.

"MY deAR SiR,--I am sure you will acquit me of any unfriendliness towards you, when, in telling you that I cannot have the pleasure of acceding to your wish, I add that I have been compelled by official considerations to make an absolute rule against giving sanitary testimonials under any circumstances whatever, and have consequently, during the past few weeks, had to refuse some dozens of applications, amongst which were many (like your own) from old professional and personal friends.

"Yours very truly,

"Wm. Bloxam, Esq." "JoHn Siman.

On the morning of the election, Tuesday, April 15th, at about ten o'clock, a vestryman put into my hands the following letter (a lithographed facsimile of Mr. Simon's handwriting):-

"SIR, - In answer to the note, in which, as a vestryman of St. George, Hanover-square, you request me to give my opinion in regard to Dr. Druitt's qualifications, attainments, and fitness for the appointment of Officer of Health, I have no hesitation in saying, from very long knowledge of Dr. Druitt, (for we were contemporaries and fellow-students at King's College some two-and-twenty years ago,) that I entertain the highest opinion of his abilities and professional accomplishments, have a sincere respect for his character, and believe he would be a most valuable officer for our parish.

"You will, of course, understand that I write this without intending prejudice to the claims of other persons, for I really do not know who are the other candidates for the appointment.

"I will beg that this may be considered as written at your request, and solely for your information; and

"I am, Sir, your faithful servant,

“J. E. Evans, Esq., 135, New Bond-street." "JoHry SIMrov.

This letter was quietly canvassed with, and not generally circulated, amongst the members of the vestry, till the morning of the election - too late for me to make any allusion to it.
On that day, accompanied by a note of urgent solicitation from Mr. J. E. Evans, and by a printed circular from Dr. Druitt, it was enclosed in an envelope, signed on the outside, "R. Druitt," and bearing the post-mark, "Curzon-street."

Ten minutes after it had been put into my hands, I accidentally met Mr. Simon, in Duke-street, showed him the letter of the 30 th of November, and that of April 4th, and requested an explanation.

He called my attention to the last two paragraphs of the letter, and told me he considered it a private letter, and that "Mr. Evans had made a dishonest use of it," which I had his permission to repeat.

I then wrote the following to the Chairman of the Board, and placed it personally in his hands.

“ 29, Duke-street, Grosvenor-square, April 15th, 1856.

"SrR, -A lithographed copy of a letter from Mr. Simon, Medical Officer of Health to the Central Board, addressed to J. E. Evans, Esq., having been this morning circulated amongst the vestry by Dr. Druitt, I am authorized by Mr. Simon to say that 'a dishonest use has been made of his letter,' he having declined to give any testimonial to myself or to any candidate whatever.

" I shall feel obliged by your reading this communication to the vestry, at the commencement of their proceedings; And have the honour, \&c.

\section{"To the Chairman of the Vestry of}

st. George, Hanover-square."

"W. BLoxaMr

This letter was not read, nor any allusion to it made, as far as those gentlemen of the vestry who supported my pretensions are aware.

I have now placed before you the facts of the case;

And have the honour to be, Sir, yours most obediently, Duke-street, Grosvenor-square, April $22 \mathrm{nd}, 18 \overline{2} 6$.

\section{MEDICAL ETHICS.}

\section{To the Editor of THE LANCET.}

SiR,-I trust you will allow me to make a few remarks on Mr. Crummey's letter of the 19th inst., which he commences by a quotation illustrative of $\mathrm{my}$ infelicitous composition; but is the gentleman more felicitous in his composition, when he states in his letter, "after a careful examination of the limb, the thigh was alone complained of"? and at the close of his communication he leaves the profession to suppose he might have overlooked the fracture, which is very probable, as the mon and his friends declare that he only glanced at the limb, and ordered an onion poultice. With regard to Mr. C.'s proposition, I considered it the crowning point to his previous impertinent interference. The man was then my private patient, and before making his proposal, Mr. C. knew very well that, in consequence of his ungentlemanly conduct towards me, any suggestion emanating from him would be treated with the greatest contempt.

Mr. Crummey states that I sought the assistance of a "private friend" in the case. This is incorrect. I have never met Mr. Wm. Richardson excepting on professional matters. This gentleman has had considerable experience in every branch of the profession in Stockton during the last twenty years, twelve of which he has been surgeon to the Dispensary; he is also one of her Majesty's justices of the peace, and well known as a man of honour and strict integrity of conduct; and Mr. C.'s statement that his certificate was rejected by the club is not correct.

The "aged and established" practitioner, on a former occasion, refused to meet me in medical consultation, being a "young man;" still he did not hesitate to call in the "young man" to perform an amputation for him. Although young in comparison with Mr. Crummey, "age and experience" are not always synonymous with skill, and it is a question whether I may not have seen more surgical cases during the few years I have been in practice than $\mathrm{Mr}$. Crummey during his five-andtwenty years at the little agricultural town of Stokesley, num. bering about 2800 inhabitants. Mr. C. would do well to confine his "golden rule" and moral teachings to his own household. The admonitory style ill becomes one professional man to assume to another, through the pages of your publication; and I may be excused if I remind him, in the same friendly tone, that an onion cataplasm is not exactly the remedy for a contusion or a fracture.- - I am, Sir, your obedient servant,

Middlesbro'-on-Tees, April, 1856.

${ }_{*}^{*}$ Here this controversy must end.-ED. L. 